\title{
Inclusive education services for the blind: Values, roles, and challenges of university EFL teachers
}

\author{
Alies Poetri Lintangsari, Ive Emaliana \\ Faculty of Cultural Studies, Universitas Brawijaya, Indonesia
}

\begin{tabular}{l} 
Article Info \\
\hline Article history: \\
Received Dec 10, 2019 \\
Revised Mar 1, 2020 \\
Accepted Apr 1, 2020 \\
\hline Keywords: \\
Blind students \\
English as foreign language \\
English language teaching \\
Inclusive pedagogy \\
Universal learning design
\end{tabular}

Corresponding Author:

Alies Poetri Lintangsari,

Faculty of Cultural Studies,

Universitas Brawijaya,

Jl. Veteran, Indonesia.

Email: alieslintang@ub.ac.id

\begin{abstract}
Implementing inclusive education, the process of providing all learners with equal educational opportunities, is a major challenge for many educational systems worldwide, for it requires changes to values, system, and practices. In the teaching of English as a foreign language (EFL) in university, teachers are expected to be able to select, transform, or augment Universal Design for Learning (UDL), and Differentiated Instruction (DI) as a framework to guarantee accessibility of all learner types to the learning environment by employing specific educational design guidelines, to fit their leaners', notably for the blinds. Data on what has led EFL teachers to join the reform of the teaching instruction and how they tackle problems during implementation cannot be located. Thus, the aim of this qualitative study is to uncover reasons for EFL teachers to participate in and what they did to facilitate the instruction wide effort to practice inclusive education, as well as challenges encountered. Key findings included implementing university policy as prime reasons for practicing inclusive education, utilizing UDL and DI as the key to successful implementation for instructional teaching, and inadequate resources and teacher training as the main challenges. Recommendations consists of providing disability-specific pre- and in- service training programs for teachers and making arrangements of sufficient educational materials and assessment based on UDL and DI towards EFL instructions.
\end{abstract}

This is an open access article under the CC BY-SA license.

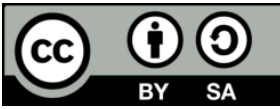

\section{INTRODUCTION}

Amid ongoing global discussions about inclusive education, Indonesia is implementing it as a costeffective alternative to educate students with different abilities, like students with blind, deaf, mute under several bases. In the 1970s United Nations Educational, Scientific and Cultural Organization [1] recommended that developing countries implement inclusive education [2]. In the latest Incheon Declaration of World Education Forum in South Korea in 2015 [1] distinctly acknowledges inclusion and equity in education of people with disabilities. Furthermore, United Nation [3] sustainable development goals incorporated inclusion of disability in education goal. Not with standing these international commitment and progress in international level, universal and inclusive education of people with disabilities in Indonesia further to be accomplished. Moreover, research reported by [4] that the students with disabilities endorsed their interest to attend college higher than those without disabilities. As a result, interest over inclusive education in every level of education in Indonesia has been growing. 
Although aggregate and constructive attempts from stakeholders of the community are entailed to promote and carry out inclusive education in every level of education in Indonesia, simply placing students with disabilities into mainstream classes together with peers without disabilities appear to comprise its implementation. Notably in tertiary level of education, inclusive education scope extends beyond to cover all students with special educational needs, whatever their origin [2]. It also goes far beyond the mere placement of such students in regular classes to include consideration of multiple dimensions of education [5]. These are in line with the impetus of United Nation's [6] convention on the rights of people with disabilities. Consequently, in university, students with different abilities, like blinds have the same opportunities and educational experiences as those provided for sighted students. Students who are blinds have been integrated in general education schools with their sighted peers and required to intact the same curriculum and examinations [7].

Despite limitations that people who are blind experience, they process most cognitive information much as do students with sight. Without vision, blind students are left to assemble information through a compensatory medium like tactile or auditory sense, putting them at a primary disadvantage [7]. They compensate for visual loss utilizing perceptual information acquired via haptic, auditory, and olfactory senses [8]. Nonetheless, distinction between blind students or sighted is present in the modes of information collection, yet in the cognitive structures and operation processes, the differences fade [9]. When studying in the university, blinds students experience learning English as a foreign language (EFL) as one of compulsory courses to take in their first year, so, EFL teachers need to prepare instructional materials, media, and techniques which can accommodate all students learning process. Equal access to learning materials [10], guides on how to teach EFL [11] variety of assessment methods are some significant facets to provide by English teachers.

Given that little research has examined application and impacts on implementing exclusive education for blind students in university and that EFL teachers have called for providing indistinguishable opportunity to learn, this study is aimed at reporting EFL teachers' values, roles, and challenges when accommodate instructional practices in English classes. The case study reported here is part of larger project where inclusive education is applicable to various students with different abilities. Consequently, many questions remain about how EFL teachers can be specifically prepared, supported, and rewarded in their positive effort to inclusion. There is a need to rethink challenges of developing, supporting, and valuing inclusive EFL teachers from a perspective curriculum under the basis of considerable policy related to inclusive education.

Access to higher education for students with disabilities remains discriminated although Indonesia has enacted regulation on it through Law no. 20 of 2003 on National Education. Still, the implementation of inclusive education are challenged by the lack of understanding on policy, philosophy, practices, infrastructures and teacher capacity [12]. Students with Disabilities who wants to access higher education do not receive any accommodation and only accepted in Pendidikan Luar Biasa (education for special needs department), thus, only universities that provide this department that can accept students with disabilities, unless they should fight alone. Moreover, Indonesia national higher education entrance examination excluded participants who are deaf and blind, consequently, only students with physical disabilities who can access the university [13]. Rizky elucidated that only $0.95 \%$ (36) out of 3794 people with disabilities who got an undergraduate degree [14]. This illustration put the discrimination against people with disabilities in accessing education more visible. The education system in primary and secondary level which is called Sekolah Luar Biasa (segregated special needs school) is viewed as discrimination since this education system not only segregating SWD in a learning situation but also the curriculum level [15]. This condition put students with disabilities in a rock bottom, the segregated education system has put them in exclusion, moreover the downgraded curriculum put them in uncompetitive position compared to peers from general school.

As the ratification of CRPD in 2011 through law no. 19 of 2011, access to education for people with disabilities sounds to be more obligatory. Inclusive Education for students with disabilities seems facing new light as a way to reduce the discrimination of people with disabilities in education. Access to higher education for students with disabilities is also wide open since their right is guaranteed by the regulation of Ministry of Research, Technology and Higher Education No. 46 of 2017 about Special Needs Education. This regulation impulses Universities in Indonesia to welcome and provide services for students with disabilities by forming Centre for Disability Services.

Years earlier, two Universities, UIN (Islamic State University) in Yogyakarta and Universitas Brawijaya in Malang have pioneered centers for disability services. UIN has formed a canter for disability services since 2007 while Universitas Brawijaya has formed a canter for disability services in 2012. Both of universities provide almost the similar services for students with disabilities such as sign language interpreter, volunteer for book digitalization, accompanier for the blind and wheel-chair user and conducting

Int. J. Eval. \& Res. Educ. Vol. 9, No. 2, June 2020: 439 - 447 
research and project related to inclusive encouragement in Indonesia. One that makes difference between two institutions that Universitas Brawijaya provides affirmation action through an annual selection program called SPKPD, an annual selection designed specifically to grant students with disability access to enroll higher education apart from the National University Selection. This special selection is designed recalling twofold, (1) the national university selection has not been providing accessible test for applicants with disabilities and (2) the previous level education of students with disabilities, specifically those graduated from Sekolah Luar Biasa (Segregated schools for students with disabilities), were not prepared them for higher education. This affirmative program is considered as a way to speed up equality for students with disabilities to get access to higher education. This affirmative program places Universitas Brawijaya as favorite university for students with disabilities. From 2012 until 2018, there have been 124 SWD with various disabilities studying in Universitas Brawijaya. The center provides services for SWD in terms of the academic activities but less attention given to the teaching practices. Consequently, most of lecturers who teach students with disabilities in their class are less equipped in providing access and curriculum adjustment to facilitate students with disabilities.

Blind is the conditions of total visual loss that affects the learning process. Blind students cannot use their vision for learning; therefore, they have to optimize their other senses to gather information, such as hearing and tactile senses. Others barriers due to blindness beside the absence of visual input are delayed development on cognition, language, personal and social adjustment. Beside the challenge in understanding the visual concepts such as colors, three dimensional spaces, shapes and so on, lack of vision can hamper the cognitive development since it limits the unifying experience of the visual sense deliver innately to the sighted children [16]. Blindness can also lead to the delay of language development, although blind children develop formal language normally, they seem have difficulties regarding pragmatic language such as the ability to use language in social context [17]. Moreover, blindness invites major efforts in vocabulary development, since they are slower forming hypotheses about word meaning compared to sighted children. Blind children are restricted to comprehend word meaning from their personal experience compared to sighted children whose vision help them broaden and generalize the meanings of words. Regarding to the restricted mobility and limited experience of blind children appear to cause the state of passivity and dependency [16]. In the above-mentioned illustration, the developmental delays of blind children due to the lack of vision frequently occur. Thus, the teacher needs to consider the barriers faced by the blind students to designing instructional teaching for blind students. In the context of classroom activities, blind student may encounter some problems related to academic activities such as reading, writing, and others. According to [18], blind students face some barriers in terms of reading, in-class activities, and finding references as elucidated in Table 1 .

Table 1. Barriers, accommodation, and assistive technology for blind student [19]

\begin{tabular}{|c|c|c|}
\hline Barriers & Accommodation & Assistive Technology \\
\hline $\begin{array}{l}\text { Blind students cannot access } \\
\text { reading materials in a } \\
\text { printed forms }\end{array}$ & $\begin{array}{l}\text { Providing the reading materials in an accessible format such } \\
\text { as word, pdf or e pub. }\end{array}$ & $\begin{array}{c}\text { Screen Reader such as JAWS } \\
\text { or NVDA }\end{array}$ \\
\hline $\begin{array}{l}\text { Blind students cannot access } \\
\text { visual concepts such as } \\
\text { diagram, colors, table, and } \\
\text { so on }\end{array}$ & Teacher needs to describe the visual concepts & $\begin{array}{l}\text { Alt text or alternative text } \\
\text { attached to the picture so the } \\
\text { blind student can have a clear } \\
\text { description on the picture. }\end{array}$ \\
\hline $\begin{array}{l}\text { Blind students are struggling } \\
\text { in taking note, summarizing, } \\
\text { and understanding all lecture } \\
\text { materials presented in visual } \\
\text { concepts. }\end{array}$ & $\begin{array}{l}\text { Teacher should provide the materials before the class so the } \\
\text { blind students can have an enough time to learn in. Teacher } \\
\text { can allow blind students to record and use their handheld } \\
\text { devices during the lecture. }\end{array}$ & $\begin{array}{l}\text { Slate, Stylus, Picture } \\
\text { Descriptor Software such as } \\
\text { cloud vision, note taking } \\
\text { software such as Evernote, } \\
\text { write pad and so on. }\end{array}$ \\
\hline Written examination & $\begin{array}{l}\text { Teacher can provide reader that assist the blind students to do } \\
\text { the exam. Reader will help the blind students by reading them } \\
\text { the question and writing their answer on the answer sheet. } \\
\text { Alternatively, teacher can design examination that is } \\
\text { accessible for blind students such as providing the } \\
\text { examination in form of audio, braille or word file. }\end{array}$ & $\begin{array}{c}\text { Recorder, Laptop, Braille } \\
\text { Translation software, Braille } \\
\text { Printer. }\end{array}$ \\
\hline
\end{tabular}

Universal Design Learning (UDL) is the basic theoretical framework to guide the development of curriculum, which is flexible and supportive for all students. It is developed by CAST that was inspired by the concept of Universal Design movement in architecture that anticipates the needs of individuals with disabilities and accommodates their needs from the beginning. Though it is initially made for an individual with a disability only, it offers the foreseen benefits for all users. For example, the existence of curb cuts not only benefits the wheelchair users but also benefits parents using stroller, children or even walkers. Likewise, UDL is designed to meet the needs of all students at the beginning by providing the methods, materials 
and assessment are usable and accessible by all according to the three means of principle; (1) Support recognition for learning, provide multiple, flexible method of presentation; (2) Support strategic learning, provide multiple, flexible method and apprenticeship and (3) Support affective learning, provide multiple, flexible option for engagement. Universal Design Learning framework can facilitate a flexible, responsive curriculum that help teachers to minimize the learning barriers and encourage self-motivated and autonomous learner [19] since teaching approach and teacher attitude are found as the foremost factors that can be positively and negatively affecting student engagement in language learning [20].

Differentiated Instructional Strategies (DIS), on the other hand, offers teachers to plan teaching strategies to achieve and fulfill the needs of learners with the varied characteristics. Differentiated Instruction is well established as practices that may be well-matched to the three principles of UDL. As the first principle of UDL is recognition for learning that focuses on the pattern recognition and the importance of providing the multiple and flexible method, this principle in line with the DI theory that incorporates some guideline to help the teacher to support students' recognition learning in a flexible way and enhance students' success. The second principle of UDL also incorporate with DI theory since DI lead the teacher to provide information and skills in multiple times and at the varying level, it meets the strategic learning, the second principle of UDL that emphasize the varied teaching strategies to meet the most desirable method of learning. Both DI and UDL emphasize the important point of convergence that is the recognition to engage students in the learning process, specifically the instructional task. DI is effectively supporting the third principle of UDL Affective learning by reinforcing the need for effective classroom management to enhance students' engagement. Therefore, DI encourage the teacher to offer choices of tools, adjust level difficulty and provide varying levels of instructional task [21].

Drawing on Gregory \& Chapman, "Differentiated Instruction is a philosophy that enables teachers to plan strategically in order to reach the needs of the diverse learners in the classroom today" [22]. Differentiation needs to be done since today there very diverse characteristics and needs that students face, including SWD. Teachers need to consider their teaching according to students' readiness, preferences, and interest. To point out, DI provides a variety of options to successfully meet the learners need so they can challenge their appropriate option to reach their best achievement. There are three elements in a curriculum that can be differentiated; (1) Content; (2) Process and (3) Product. In adjusting the content, lecturer needs to include acts, concepts and generalizations or principles, attitudes and skills and make sure that students can access the content. Despite providing the content adjustment in terms of materials, lecturers also need to differentiate instruction and objective. Goals of learning should be frequently assessed according to manystate level, the task using the structured standardized measures. The continuing and flexible assessment also benefit in diagnose students need in the learning process. Flexible grouping is considered a one way to facilitate the learning process. It is expected that students interact and work together as they develop their understanding of the content. The flexible grouping should be done in a dynamic process followed by on-going evaluation. Product differentiation should consider the previous steps by considering the initial and on- going assessment; lecturer can plan functional and successful differentiation. Lecturer also need to varying expectation and requirement to the student response that allows the lecturer to design a student product that offers varied means of expression, alternative procedures, and offers varying degrees of difficulty, types of evaluation and scoring [23].

The initial step the lecturer needs to do is doing students pre-assessment to be the basis of DI planning. The pre-assessment planning can be done either formal or informal. The lecturer can assess the cognitive performance and affective performance that is done through the ongoing assessment using formal and informal tools. After the information gathered, lecturer interprets the data to be used as the basic data to plan the DI strategically. Lecturer needs to do the six-step to planning the DI, the first thing is planning the standard, outcomes, and expectation by explicating clearly on what and how the students need to know, and assessment strategies. Second, lecturer needs to plan the content according to the accessibility and varying state-level. Third, lecturer activates prior knowledge of students to bridge them with the content. Activating prior knowledge can use the flexible grouping and series of task that trigger challenge, novelty, and experiences of the students. Fourth is the step of deciding about how the students acquire the knowledge. Fifth, the step where the lecturer finally applies and adjusts the designed strategies and the last is assessing the student by deciding or providing choices on how the students will demonstrate their knowledge or competencies. The vital point in implementing the DI in the diverse needs of students, lecturer need to have an on-going assessment and flexible teaching strategies and method to meet the need of SWD in the class [24].

Int. J. Eval. \& Res. Educ. Vol. 9, No. 2, June 2020: 439 - 447 


\section{RESEARCH METHOD}

The participant was an EFL teacher who taught English for non-English department. She taught one blind student in the first semester. The focus of this English course was to develop students' comprehension on expository essay reading skills for supporting their study. The class met once a week for 16 weeks, which constituted reading, speaking, writing, and listening activities. Students in the class were required to brainstorm, discuss, listen, and present to the class.

Case study design employed to reveal descriptive data via qualitative approach. Data saturation was obtained from data triangulation through several procedures applied. First, EFL lecturer was interviewed about the blind student and her planning about instructional methodology, media, and materials. Secondly, through observation, the researcher monitored EFL teacher's activities in the class meeting and the blind students' activities. Thirdly, interviews with the blind student's classmates were conducted to confirm trustworthiness of information obtained. The results of EFL teacher interviews, observations, and student's classmate interviews were arranged into EFL teacher's values, roles, and challenges.

\section{RESULT AND DISCUSSION}

\subsection{The voice of blind student}

This finding elaborated the result of interview of the blind student and classroom observation. The result of the interview revealed that the blind student has challenges in mobility, access to accessible materials and group work. Since his orientation mobility skill is quite weak, he always needs the peer support to assist him in mobility. His challenge on mobility also shown in observation session, he seems dependent on peer support for every little movement such as mobility when group session, preparing his laptop in his desk, and go to the rest room. In term of Learner Input, the blind student has understood the topic of the course; he also has known the objective of the course. It means that the student is self-prepared to access the lesson. Related to learning style and learning needs, the blind student preferred the quite situation with minimum noise to study. The student class performance, he argued that his academic performance was not optimally achieved since the materials, task, and instruction mostly were not accessible for him. Although prefer to studying in a group, he confessed that some barriers obstructed him to actively involved in the group discussion due to lack of information (the inaccessible materials and instruction). He also mentioned the need of a volunteer who helps him to mobile, describe the situation and assist him on field trip assignment. Elaborating his needs in learning, he also mentioned on some accommodation that he needs to elevate his independence and self-efficacy such as the availability of guiding block in every street, accessible books and materials and peer support to assist him in out of college activities.

\subsection{Teaching English for the blind student: strategies and challenges}

Teaching English as Foreign Language for blind student in a mainstream context requires a modification in instructional teaching practices. Integrating the values of Universal Learning Design and the concept of Differentiated Instructional Strategies is the efforts performed by the EFL teacher being observed in this research to accommodate the blind student in her class. The researcher developed the observation guide following the teacher guide toward differentiation designed by Chapman \& King that cover 5 indicators (1) Physical Environment, (2) Lecturer Behavior, (3) Students Engagement, (4) Material or sources, and (5) instructional strategies.

In terms of physical environment, the teacher is recognized always present an inviting and relaxed environment and put the blind student in the seating position with minimum noises so he can access the lecturer explanation as well as possible. Although the class and chair is designed for quick and easy grouping so the students can easily move if any grouping session, but it limits blind student moves since the desk is way too small shown in Figure 1 while the blind students need more spacious desk for his laptop.

The researcher recognized the classroom seating arrangement in in u-shape arrangement by putting the blind student in the center of the $U$ shape as seen in Figure 2. The U-Shape seating arrangement is considered effective to reach all of the students. By arranged the students seating in U Shape, the teacher can see each of the students and control their engagement, included the blind student. By positioning the blind student in the center of the seating arrangement, it allows him to access teacher information and explanation.

Teacher behavior in accommodating blind student needs covering some efforts such as verbalizing all the visual concepts she displays in her slides, provide lecture hand-outs and Power Point presentation in priority order by uploading it in Google classroom so every students including the blind student can access it. Group work is the main concern of the teacher to uplift the involvement and engagement of the blind student in the class. Flexible grouping strategies chosen by the teacher to allow the students exposed to various learning experiences with various characteristics of peers. By exposing the blind student to various grouping condition, it is expected that it will minimize his passivity and dependency to his close friends. 


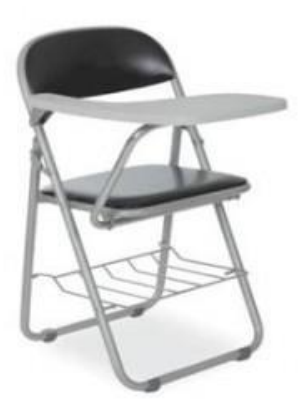

Figure 1. The classroom chair

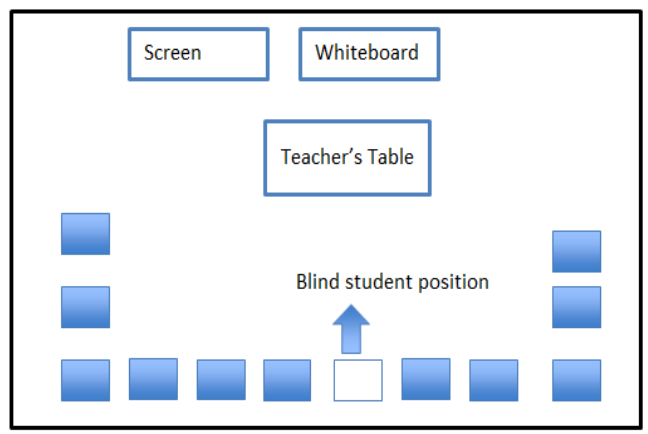

Figure 2. U shape classroom seating arrangement

To enhance the blind student engagement in class, teacher provides material and resources that is accessible for blind students in form of word files and Google classroom activities. By providing this format of materials and resources, blind student can optimize his engagement in class activities. The use of Google classroom covers almost all learning activities for the blind student, such as the materials sources, assignment portal, and discussion. While for the in-class assignment, the lecturer make differentiation by providing the assignment on line via Google classroom or what's app for the blind student so he can work it independently and reduce his dependency to his peer support. Alternative examination arrangement is also made to meet blind student by providing oral examination instead of paper based exam. The use of ICT based media is also alternative promising to accommodate not only blind students but also other students as it is relevant to the [23] that $95.5 \%$ of students believes that social networking is beneficial for learning process. Likewise, today students have high digital literacy scale and perceived readiness toward the digital technology into English learning [24].

Aside from the efforts made by the teacher to accommodate blind student in ELT class, challenges in providing those accommodation is real. A further problematic issues faced by the teacher are (1) Access to accessible textbooks used in classroom is limited. The teacher has provided the textbook in PDF-JPG based format so it cannot be read by screen reader. The teacher has asked the student to contact disability services to convert the textbook into OCR format but it came to waiting list, so the blind student cannot get the accessible format in time; (2) Sound-letter inconsistency in English language resulting challenge for the teacher to teach English Pronunciation. Blind student tends to do error in spelling in form of omission of word ultimately in word involving double consonant and silent letter; (3) Physical Environment of the campus building that is mostly inaccessible for the blind and classroom desk and chair that do not support blind student movement because it is too small (as seen in Figure 1); (4) The Blind Student has skilled in accessing the digital material but his engagement is less optimal since he lack of initiative and orientation mobility. He also tends to doze off while listening to the teacher's explanation, thus, the teacher needs to call his name in ten until twenty minutes once to make sure that he is awake and following the lecture and (4) Teacher lacks of knowledge, skills, experience and inadequate resources in accommodating blind student in ELT class.

Aforementioned narratives have shown that the inclusion of blind students in mainstream context benefits the teacher to encourage and seek for the new approaches in facilitating deaf students. As Eser [25] has proven in their study that blind students' is that the great majority of blind students has successfully gained the learning outcomes in science that required more visual inputs rather than language learning. Hence, the inclusion of blind students in learning language should be easier to facilitate.

\subsection{EFL teacher value, roles and challenges for teaching blind student}

The teaching process of blind students in inclusive class required multiple ways of teaching method. Considering learning preferences and learning styles are also affecting the students' academic performance [26]. The blind students need variety of opportunities in exploring and examining the learning materials through alternative sense beside visual inputs such as tactile and audio input [27]. Finding of the research clearly indicate the EFL teacher of the blind student is highly-committed in providing access and accommodation for the blind student in her class though she needs to spend extra energy and extra time to prepare the instructional teaching that is accessible and meet the blind student needs. According to her point of view, as a teacher as teachers who are required to possess professional compulsory competencies, i.e. pedagogic, professional, social, and personality competencies [28], we should be fair in welcoming our various students. Since inclusive education matters, not only multicultural experiences and various students'

Int. J. Eval. \& Res. Educ. Vol. 9, No. 2, June 2020: 439 - 447 
attitudes and efficacy in learning as stated in [29, 30], but also in the teaching and learning for students with disabilities $[26,29]$. Teaching blind students, a teacher needs to consider that a blind student is a student first and seeing his blindness as the innate characteristics as other students have. By framing the perspective this way, a teacher will see having a blind student in her class as an opportunity to limitless exploration of teaching technique and experience rather than seeing it as a burden. Moreover, the efforts of accommodating the blind student in a mainstream context is a part to fulfilling the policy as explicated in the regulation number 46 of 2017 published by ministry or research, technology and higher education. She explained that in the aforementioned regulation, higher education should facilitate learning process and assessment method suitable to the needs of students with disability without downgrading the quality of learning. The learning process should be adjusted in terms of learning materials, teaching media and tools, learning process, assessment method and also the teaching environment. Preferably, the preparation of the curriculum should consider the flexible teaching method and tailor the teaching environment to the needs of the students [26].

In the practical level, the teacher self-efficacy -the feeling of being capable at doing something- [31] will affect the practices of teaching in inclusive class. Teacher with a positive self-efficacy will positively respond to the diverse characteristic of the diverse students including the blind. Modifying the accessible instructional teaching by unifying the philosophy concepts of Universal Design Learning and Instructional Design is time consuming so the teacher needs to spare her time and energy. However, those efforts are worthy made recalling that the modification is not only benefit blind student but also other students. Putting the values of education for all through the implementation of Universal Design Learning for the blind student, the teacher considers that it is an ongoing process that requires evaluation in each stage to make sure that the strategies meet the blind students need and enhance his engagement on the learning process. Though she has been encouraged to accommodate blind student in her class, challenging issues related to infrastructure, accessible textbooks access, blind students' self-efficacy, assistive technology and teaching method are challenges she has to encounter ahead. Therefore, to support the teacher performance in facilitating blind students, the role of the institution is significant to designing and enforcing policy that support inclusive practices, providing capacity building training for lecturer on disability awareness and the concept of Universal Design Learning, and providing the infrastructures such as internet connectivity and the availability of constant electricity [32]. The role of institution to support the inclusive learning environment is essential since the institution is a catalyst to reforms and rebuild the learning process and ensuring the sustainability of the inclusive practices [33]. Additionally, benefiting the use of technology will help the engagement of blind students in inclusive context, integrating education and technology in learningteaching process can support effective and productive success in education [34] though the consideration of using ICT may be preferred by the students learning style and students online regulated learning [35]. The implementation of inclusive education should involve the all three stages, input, process and output [36] and should emphasize the framework of Universal Design Learning where all students are well accommodate and well accepted..

\section{CONCLUSION}

Encouraging inclusive education for students with disabilities in higher education has been well enforced by the Indonesian government through various laws and regulations. Nonetheless, the practices of welcoming and accommodating student with disabilities in higher education still need a lot of supports and enforcement. Challenges not only comes from teacher believe on the practices of inclusive education weather it may work or not, essentially, it lays on the lecturers' perspective, skills and experience on the technique in teaching and accommodating students with disability in mainstream context of higher education. Inclusive practices of language teaching for blind students not only rely on teacher's performance, but also institution support in terms of policy and infrastructure supports. The institution should be able to cultivate the inclusive culture through their policy and practices. In the practical level, the institution should provide the series of training for all lecturers on inclusive education philosophy and practices weather they teach students with disabilities or not. Equipping lecturers with the basic philosophy of inclusive education by disseminating the concept of Universal Design Learning and Differentiated Instructional Strategies should begin momentarily regarding to the growing numbers of students' diversity and students with disability in higher education. In the effort of inclusive education implementation, the role of the ministry of research, technology and higher education as the vocal point should enforce the implementation of inclusive education by enacting regulations that supports lecturers capacity building in terms of inclusive education in a practical level such as forcing the university to design training toward inclusive education practices and oblige the lecturers to attend the training as a requirements of their career path. Moreover, the inclusion of students with disability in higher education should be supported by the previous educational background. The primary and secondary education level is advised to be able equip their students with disability with college readiness 
to support their preparedness entering the university life. Enforcing their independent and their learning autonomy is also significant in supporting their higher education survival. To sum up, the inclusion of students with disability in mainstream higher education context is not a one-man work. In needs a collaborative effort among the policy makers, middle management and the teachers, not to mention the parents of the students should also disseminate the same concept of inclusion.

\section{REFERENCES}

[1] UNESCO, "2015 World education forum," 2015.

[2] K. Lamichhane, "Teaching students with visual impairments in an inclusive educational setting: a case from Nepal," International Journal of Inclusive Education, vol. 21, no. 1, pp. 1-13, 2016.

[3] United Nation, "World education forum," United Nation, 2015.

[4] K. Bowlen, K. Osiniak, T. Syms, and K. H. Larwin, "Predictors of educational outcomes of students with multiple disabilities: results from a national study," International Journal of Evaluation and Research in Education (IJERE), vol. 7, no. 3, p. 176, Sep. 2018.

[5] D. Mitchell, "Inclusive education is a multi-faceted concept," Center for Educational Policy Studies Journal, vol. 5, no. 1, pp. 9-30, 2015.

[6] United Nation, "UN flagship report on disability and sustainable development goals," United Nation, 2018.

[7] O. Lahav, N. Hagab, S. A. El Kader, S. T. Levy, and V. Talis, "Listen to the models: Sonified learning models for people who are blind," Computers \& Education, vol. 127, pp. 141-153, 2018.

[8] V. E. Bishop, Teaching visually impaired children. Springfield: Charles C Thomas Pub Ltd, 2004.

[9] Amir Amedi, R. Noa, P. Pazit, M. Rafael, and Z. Ehud, "Early 'visual' cortex activation correlates with superior verbal memory in the blind," Nature neuroscience, vol. 6, no. 7, pp. 758-766, 2003.

[10] R. Opertti and J. Brady, "Developing inclusive teachers from an inclusive curricular perspective," Prospects, vol. 41, no. 3, pp. 459-472, 2011.

[11] Y. Jim, T. Martha, J. Bielinski, and A. House, "The relationship between instructional and assessment accommodations," Journal of Learning Disabilities, vol. 34, no. 3, pp. 212-220, 2001.

[12] Esty Zyadatul Khasanah, "Inclusive education: in concepts, policies, and implementation," Indonesian Journal of Disability Studies, vol. 5, no. 2, pp. 166-169, 2018.

[13] D. Afryanti, "People with Disability: Locked out of learning?" The University of Melbourne, 2015.

[14] U. F. Rizky, "Inclusive campus policy for people with disabilities: Study of advocacy for inclusive campus policy at Brawijaya university (in Bahasa)," Indonesian Journal of Disability Studies, vol. 2, no. 1, pp. 1-8, 2015.

[15] Irwanto, E. R. Kasim, A. Fransiska, M. Lusli, and O. Siradj, "Situation analysis of persons with disabilities in Indonesia: A desk review (in Bahasa)" Pusat Kajian Disabilitas, 2010.

[16] S. Kirk, J. J. Gallagher, M. R. Coleman, and N. Anastasiow, Educating Exceptional Children, Boston: Houghton Mifflin Harcourt Publishing Company, 2009.

[17] K. Verdier, "Children with Blindness: Developmental aspects, comordibity and implication for education and support," Stockholm University, 2018.

[18] A. Pratiwi, A. P. Lintangsari, U. F. Rizky, and U. W. Rahajeng, Disability and Inclusive Education in universities (in Bahasa). Malang, Indonesia: UB Press, 2018.

[19] Rufii and Dyah Rochmawati. "Evaluation of universal design for constructivist-based statistics learning module for students' increased motivation," Journal of Education and Learning (EduLearn), vol. 13, no. 3, pp. 431-440, 2019.

[20] A. P. Lintangsari, I. Emaliana, and Fatmawati, "Blind student's engagement in language learning: challenges and opportunities," in International language and tourism conference, Pagoh, Malaysia, vol. 3, pp. 224-234, 2019.

[21] K. Hall, "The effects of blending and segmenting decoding strategies on reading," Master's Theses Cardinal Stritch University Milwaukee, Wisconsin, 2015.

[22] Gayle Gregory and Carolyn Chapman, Differentiated Instructional Strategies; One Size Doesn't Fit All, 3rd ed. California: Corwin Press, 2004.

[23] M. Norhailawati, et al., "The power of social networking sites: Student involvement toward education," International Journal of Evaluation and Research in Education (IJERE), vol. 8, no. 3, 549-556, 2019.

[24] K. Liza and E. Andriyanti, "Digital literacy scale of english pre-service teachers and their perceived readiness toward the application of digital technologies," Journal of Education and Learning (EduLearn), vol. 14, no. 1, p. 6, 2020.

[25] S. L. Zorluoğlu, T. Ergazi, and Ş. Eser, "Learning probability of 4th grade science curriculum learning outcomes among visually impaired students," International Journal of Evaluation and Research in Education (IJERE), vol. 8, no. 3, 417-424, 2019.

[26] N. D. S. Chetty, et al., "Learning styles and teaching styles determine students' academic performances," International Journal of Evaluation and Research in Education (IJERE), vol. 8, no. 4, pp. 610-615, 2019.

[27] A. Kizılaslan, "The development of science process skills in visually impaired students: analysis of the activities," International Journal of Evaluation and Research in Education (IJERE), vol. 8, no. 1, pp. 90-96, 2019.

[28] Asrial, Syahrial, D. A. Kurniawan, P. Nugroho, and R. Perdana, "Etno-Social Knowledge: How Does Knowledge of the basic school teachers in Indonesia?" EduLearn, vol. 13, no. 4, pp. 583-288, 2019.

[29] S. Bakir, "The multicultural experiences, attitudes and efficacy perceptions of prospective teachers," International Journal of Evaluation and Research in Education (IJERE), vol. 9, no. 1, pp. 212-220, 2020. 
[30] Nithya Dewi Subramaniam Chetty, Lina Handayani, Noor Azida Binti Sahabudin, Zuraina Ali, Norhasyimah Hamzah, and Shahreen Kasim, "Learning styles and teaching styles determine students' academic performances," International Journal of Evaluation and Research in Education (IJERE), vol. 8, no. 4, pp. 610-615, 2019.

[31] T. D. Atalay, "Learning styles and teacher efficacy among prospective teachers based on diverse variables," International Journal of Evaluation and Research in Education (IJERE), vol. 8, no. 3, pp. 484-494, 2019.

[32] A. M. Jebba and N. N. Umaru, "The role of social media in reshaping the academic activities of vocational and technical education lecturers in Nigeria," International Journal of Evaluation and Research in Education (IJERE), vol. 8, no. 4, pp. 735-741, 2019.

[33] F. K. Şemin, "Competencies of principals in ensuring sustainable education: Teachers' views," International Journal of Evaluation and Research in Education (IJERE), vol. 8, no. 2, pp. 201-212, 2019.

[34] G. Tuluk and İ. Kepceoğlu, "Pre-service teachers' web pedagogical content knowledge and online information searching strategies," International Journal of Evaluation and Research in Education (IJERE), vol. 8, no. 2, pp. 229-236, 2019.

[35] I. Emaliana and I. Ismarita, "EFL students' online learning: epistemic beliefs determine learning strategies," EducaFL, vol. 2, no. 2, 2019.

[36] I. E. Robiyansah, Mudjito, and Murtadlo, "The development of inclusive education management model: Practical guidelines for learning in inclusive school," EduLearn, vol. 14, no. 1, pp.80-86, 2020. 